\title{
PERÉNYI Roland \\ A fővárosi rendőrség tagjainak II. világháború alatti tevékenysége az Igazoló Bizottsági iratok tükrében.
}

A második világháború utolsó éveiben a szövetséges hatalmak találkozóin többször is felmerült a háborús bünök kérdése. Már az 1943-as az Egyesült Nemzetek moszkvai deklarációja is foglalkozik a témával, a teheráni konferencián pedig 50000 háborús bünös megbüntetését helyezik kilátásba a szövetségesek. A háború vége felé közeledve a jaltai, majd a potsdami konferencián is hitet tettek a győztes hatalmak a háborús bünök megtorlása mellett. Ennek nyomán született meg 1945. VIII. 8-án a londoni egyezmény, amely létrehozta a Nemzetközi Katonai Bíróságot, amely a náci föbünösök nürnbergi pereinek lebonyolítását végezte. ${ }^{1}$

A háborús bünök megtorlása Magyarországon is sarkalatos kérdés volt. Az 1944. XII. 2-án Szegeden megalakult Magyar Nemzeti Függetlenségi Front programja is tartalmazta a háborús bünösök megbüntetését, a fegyverszüneti egyezmény pedig ugyancsak foglalkozott a témával. Végül az Ideiglenes Nemzeti Kormány 1945. I. 25-én kiadott rendeletében intézkedett a népbíróságok felállításáról. ${ }^{2}$ A népbíróságok amellett, hogy a háborús föbünösök ellen folytattak eljárásokat, egyben fellebbviteli bíróságként is szolgáltak a néhány héttel korábban, 1945. I. 4-től kezdődően létrejövő Igazoló Bizottságok által lefolytatott eljárások esetében. ${ }^{3}$ Az Igazoló Bizottságok célja az volt, „,hogy felülvizsgálják a közalkalmazottak és tisztviselők tevékenységét az 1939. IX. 1-je óta eltelt időszakban."4

Az Igazoló Bizottságok hét tagból álltak, mely hét tagból ötöt a politikai pártok — a Magyar Kommunista Párt, a Nemzeti Parasztpárt, a Szociáldemokrata Párt, a Független Kisgazdapárt és a Polgári Demokrata Párt — delegáltak. Ezt egészítette ki egy jogi végzettséggel rendelkező tag, valamint az igazolás alatt álló szervezet egy képviselője — utóbbi két tag az eljárásban nem rendelkezett szavazati joggal. A későbbiekben a Budapesten müködő Igazoló Bizottságokban a szakszervezetek is képviseltethették magukat. Az igazolási eljárás során ,az alkalmazottaknak nyilatkozniuk kellett, hogy politikai magatartásukkal nem sértették a magyar nép érdekeit”, valamint „el kellett mondaniuk, miként hajtották végre a hivatalos utasításokat, miért hagyták el hivatalukat (ha elhagyták) a Szovjet Vörös Hadsereg érkezésekor, mit csináltak távollétük alatt és milyen körülmények között tértek vissza."5

Az igazolási eljárás egy sajátos eljárásrend szerint zajlott. Az igazolás megkezdésekor az Igazoló Bizottság nyilvánosan kihirdette, hogy mely alkalmazottakat mikor von igazolási eljárás alá, ez alapján bárki jelentkezhetett tanúként. A rendelkezésre álló forrásokból kiderül, hogy sokszor előfordult, hogy egykori beosztottak korábbi sérelmeiket, régi konfliktusokat próbáltak megtorolni azzal, hogy denunciálták egykori felettesüket vagy kollégájukat. Az eljárás érdekessége, hogy a tanúkat nem eskették meg minden esetben, számos ügyiratban mindössze annyi szerepel, hogy a tanú, vagy éppen maga az eljárás alá vont alkalmazott „,fogadalmat” tett. A vádak ellen az igazolási eljárás alá vont kétféleképpen védekezhetett. Egyrészt a meghallgatáson kellett megszólalnia — gyakran előfordult az is, hogy maga az igazolandó kérdezett a tanútól —, másrészt minden eljárás alá vont személy igyekezett olyan nyilatkozatokat beszerezni (feletteseitől, kollégáitól, szomszédoktól, ismerősöktől), amelyekben „demokratikus magatartását” bizonyítják.

A rendőrségi alkalmazottakkal szemben lefolytatott eljárások azt a fontos elvi kérdést járják körül, hogy 1944. III. 19., Magyarország német megszállása után, valamint a nyilas uralom alatt a rendőrségi alkalmazottaknak — legyen szó közrendőrökröl, csapattisztekröl vagy akár irodai alkalmazottakról — mekkora egyéni mozgásterük volt egy háborús bünöket elkövető uralmi rendszer által hozott parancsok és utasítások végrehajtása terén, valamint hogy ők hogyan éltek — vagy éppen nem éltek — ezekkel a lehetőségekkel. Az általunk vizsgált iratok ugyanakkor érdekes betekintést adnak egy-egy rendőri alkalmazott egyéni sorsába, háborús hétköznapjaiba is, és egyúttal fontos társadalomtörténeti adatokkal szolgálnak a rendőrségi állomány összetételére, társadalmi hátterére vonatkozóan is.

Utóbbi szempontból különösen érdekesek azok a nyilatkozatok, amelyeket az igazolás alá vont alkalmazottak nyújtottak be. Így például a rendőrfökapitány-helyettes, akit azzal vádolnak, hogy kényszer nélkül hagyta el az országot, egy mintegy 200 aláírást tartalmazó ívet nyújtott be, egy főhadnagy pedig, akit jobboldali kijelentései miatt állásvesztésre ítélt az Igazoló Bizottság, a híres színésztől, GÓzON Gyulától szerzett igazoló nyilatkozatot. A nyilatkozatok részletesebb elemzése — ami jelen tanulmányunknak nem tárgya — segítségével jól kimutatható egy-egy rendőrségi alkalmazott kapcsolati hálója. 
Ugyancsak értékes forrást jelentenek azok az eljárásban nyilatkozatnak nevezett, tulajdonképpen önbevalláson alapuló kérdőívek, amelyeket minden igazolás alá vontnak ki kellett töltenie. ${ }^{6}$ A rendőrségi Igazoló Bizottsági iratok között két különbözö típusú kérdőívet találni. Az egyik — valószínüleg ezt inkább a kezdeti időszakban használták — 19 kérdésből állt, a másik jóval részletesebb, itt 45 kérdésre kellett választ adni. Mindkét „nyilatkozatból” fontos információkat nyerhetünk az igazolás alá vont személyes viszonyaira (születési hely, idő, lakóhely, iskolai végzettség, vagyoni állapot), katonai előéletére (kitüntetések, előléptetések, melyik alakulatban szolgált), rendőri pályájára (mikor lépett be, hol szolgált) és esetleges fegyelmi ügyeire vonatkozóan. A 45 kérdést tartalmazó nyilatkozatban ezen felül olyan kérdések is szerepeltek, mint például hogy milyen nemzetiségü az illető, volt-e Volksbundtag vagy SS-katona, változtatott-e nevet, és ha igen, mi volt az eredeti neve. A kérdések másik része egyesületi, párt- vagy vitézi rend-tagságára vonatkozott (a legtöbb igazolás alá vont mindössze a RAC, azaz a Rendőrtisztek Athlétikai Clubja-tagságról nyilatkozott), de rákérdeztek olvasási szokásaikra is (mely lapot olvasta rendszeresen, melyiknek volt esetleg előfizetője). A további kérdések a nyilas uralomhoz, valamint a zsidósághoz való viszonyt firtatták. ${ }^{7}$

A Budapesti Államrendőrségnél működő Igazoló Bizottságok 1945. április közepétől kezdték meg a munkát. ${ }^{8}$ Előbb két Igazoló Bizottság foglalkozott a rendőrségi alkalmazottak tevékenységével, majd június-júliusban két, októberben három újabb Igazoló Bizottság alakult, így 1945 öszén már hét rendőrségi Igazoló Bizottság működött. Ebben az időszakban az Igazoló Bizottságok közül egy kimutatás szerint öt hetente három, egy hetente négy, egy pedig délelőtti és délutáni tárgyalásokkal hetente tizenegy alkalommal ülésezett. ${ }^{9}$ Amint az a Kommunista Párt 1945. IX. 19-én az Igazoló Bizottságok Központi Titkárságához intézett leveléből is kiderül, az új irányítás a rendörségi legénység és tisztikar igazolását minél hamarabb szerette volna véghezvinni: „Feltétlenül szükségesnek tartjuk, hogy a közigazgatás e fontos karhatalmi szerve az igazolási eljárásokon mielőbb átessék. A nagy létszámú rendőr tisztikar és személyzet igazolását tehát a bizottságoknak fokozott gonddal és pontossággal kell lefolytatni." ${ }^{, 10}$ Bár a levél két egymást követő mondata nem áll feltétlenül ok-okozati viszonyban, mégis mindkét kijelentés jól mutatja, hogy a felálló új hatalom számára milyen jelentőséggel bírt a rendvédelmi szervek háborús tevékenységének felülvizsgálata.

Az eredeti tervek szerint 1945 végéig a teljes fővárosi rendőrségi állomány igazolási eljárása lezajlott volna. A Budapesti Főkapitányság november 19-én azonban azt jelentette az igazolási eljárásokat felügyelő Igazoló Bizottságok Titkárságának, hogy a hét Igazoló Bizottság müködése mellett is mintegy 10.000(!) - egy másik jelentésből kiderül, hogy összesen kb. 13000 embert kellett volna igazol$\mathrm{ni}^{11}$ — ügy van még hátra, így a teljes igazolási eljárás még nagyjából egy évig tartana. Ezért a fökapitányság kérte a titkárságot, hogy az összes Igazoló Bizottság tárgyalási idejét sürítsék heti tizenegy alkalomra, így a tervek szerint nagyjából három hónap alatt lezárulhatott volna az igazolási eljárás. Ráadásul mivel ősszel nagyszámú legénység érkezett vissza nyugati hadifogságból, ezért önmagában még a tárgyalások besürítése sem lett volna elegendő. Így a főkapitányság kérvényezte, hogy további Igazoló Bizottságokat állítsanak fel. Ennek köszönhetően az igazolási eljárás utolsó időszakában a budapesti rendőrségnél összesen tizennyolc Igazoló Bizottság müködött, az I-VI. számú Igazoló Bizottságok pedig kifejezetten „nyugatos” ügyekkel foglalkoztak.

Az Igazoló Bizottságok müködésének intenzitásáról tanúskodik a III. számú bizottság kimutatása az 1945. VI. 21 - VII. 20. közötti időszakról. Ebben az egy hónapban 28 napot ülésezett a bizottság és összesen 161 ügyet tárgyalt. Napi átlagban öt-hat esetet tárgyalt, de találkozni olyan tárgyalási nappal is, amikor mindössze egy igazolást tudtak lefolytatni. ${ }^{12}$

Az általam vizsgált levéltári anyagban összesen 277 eljárás anyaga található. ${ }^{13}$ A rendelkezésre álló iratokat két részre bontottam: külön vizsgáltam a kizárólag első fokon, az Igazoló Bizottságok által vizsgált ügyeket, illetve a népbírósághoz mint az Igazoló Bizottságok másodfokú hatóságához fellebbezett határozatokat.

A fellebbezés nélkül meghozott Igazoló Bizottsági határozatok összesen 223 ügyet takarnak, ami az összes fellelhető eljárás 80,5\%-a. Ebben a kategóriában az eljárás alá vont állomány legnagyobb része detektív, detektívgyakornok, de találunk itt rendőrkapitányokat, valamint a hivatali személyzethez tartozókat - számvevőségi ellenőröket, rendőrorvosokat, de például a rendőrségi segédhivatal igazgatóját — is. A 223 esetből 204-ben (91,5\%), „simán” igazoltnak nyilvánította a Bizottság az eljárás alá vontat, ${ }^{14} 6$ esetben $(2,7 \%)$ feddéssel, 7 esetben $(3,1 \%)$ az elöléptetésböl (többnyire egy, három vagy öt évre történő) kizárással - ebböl 1 esetben áthelyezéssel, 3 esetben pedig vezetői állásra alkalmatlannak nyilvánítással súlyosbítva - igazolták a rendőri személyzetet. A vezetői állásra való alkalmatlanság $2(0,9 \%)$ esetben szerepelt a határozatokban. Súlyosabb következményekkel járó határozatot mindössze 4 esetben találunk, ebböl $3(1,35 \%)$ esetben állástól való megfosztásról (ebböl egy sze- 
mélynél a választói névjegyzékböl való törléssel súlyosbítva) szól a határozat, 1 detektívgyakornok ügyében viszont úgy határozott az Igazoló Bizottság, hogy mivel felmerült annak gyanúja, hogy az eljárás alá vont népellenes büntett elkövetésében vett részt, ezért az állástól való megfosztáson túl népbíróság elé idézik az illetőt.

Az elmarasztaló Igazoló Bizottsági határozatokat vizsgálva kiderül, hogy a leggyakoribb ok a „jobboldali beállítottság”, ami elsősorban olyan szóbeli megnyilvánulást takar, amelyben a nyilas rendszer támogatása vagy a németek győzelmébe vetett hit nyilvánul meg. Érdekes módon a forrásokban olyan esetekre is rábukkantunk, ahol a háború utáni kijelentések miatt marasztaltak el valakit. Így például egy segédfelügyelőt azért zártak ki három évre az elöléptetésből, mert a háború végét követő napokban valami sértőt - hogy pontosan mit, az nem derül ki az iratokból — mondott egy piros karszalagot viselő rendőrre.

A legfontosabb okok között találjuk az olyan eseteket, amikor az eljárás alá vont kényszer nélkül távozik Nyugatra (többnyire Ausztriába, majd Németországba), de az indoklások között megtaláljuk a közalkalmazotti minőséggel való visszaélés - egy konkrét esetben az igazolandó detektív internálással fenyegetett meg valakit — vádját is.

A határozatok meghozásakor a beosztás sokszor súlyosbító tényezőként esik latba. Magasabb hivatali tisztség, illetve a politikai rendőrségen folytatott szolgálat esetén jóval nagyobb volt az elmarasztaló határozat esélye, még akkor is, ha az Igazoló Bizottság nem tudott semmiféle bizonyítékot felmutatni az igazolás alá vonttal szemben. Míg például alacsonyabb beosztásúaknál a Nyugatra távozás sokszor nem került olyan szigorú elbírálás alá, addig a politikai rendőrségnél szolgálóknál a két tényező - a beosztás és az ország elhagyása - együtt minden esetben állásvesztéssel járt. Ugyancsak komoly súlyosbító tényezőt jelentett, ha az igazolás alá vont a zsidóktól elkobzott lakást igényel és be is költözik egy ilyen lakásba.

A második csoportba tartozó, népbírósághoz fellebbezett Igazoló Bizottsági ügyek között összesen 54 esetet találunk, ebböl azonban csak 39-nél ismerjük a másodfokú határozatot. Utóbbi eseteknél legtöbbször, 30-szor (77\%) megváltoztatta az elsőfokú határozatot a népbíróság és csak 9 (23\%) esetben hagyta helyben. A népbíróság - egy kivétellel, ahol az eredeti, állásvesztésről szóló határozat mellett (mivel bünügy elkövetésének gyanúja merült fel) bíróság elé utalták az ügyet -29 esetben enyhít az Igazoló Bizottság által hozott határozaton. Ezek közül 27 esetben az elsőfokú határozat állásvesztést mondott ki, amit a népbíróság 10 ügynél „,simán” igazoltra változtatott, ${ }^{15} 8$ esetben az állásvesztést vezetői állásra alkalmatlanná nyilvánító határozatra, a többi esetben feddésre, kényszernyugdíjazásra vagy az előléptetésből néhány évre történő kizárásra enyhített. Két olyan esettel találkoztunk, ahol nem állásvesztést kimondó Igazoló Bizottsági határozat nyomán fellebbezett az igazolt: egy esetben a kényszernyugdíjazásról szóló határozatot másították meg „simán” igazoltra, a másik esetben pedig a feddést, vezetői állásból és előléptetésből történő kizárást enyhítették feddésre.

Az Igazoló Bizottsági határozat ellen fellebbezők között elsősorban közép-, és magasabb beosztásúakat - rendőrfelügyelőket és főfelügyelőket, rendőrtanácsosokat, kerületi rendőrkapitányokat, a rendőrségi ambulancia vezető orvosát, sőt a rendőrfőkapitány-helyettest — találtam. Arra is van példa, hogy egészen alacsony beosztású alkalmazottak — köztük egy takarítónő és motozó —, rendőrségi írnokok, közrendörök fordulnak a népbírósághoz jogorvoslatért.

Az Igazoló Bizottság elmarasztaló határozatát kiváltó vádak itt is hasonlóak, mint az előző csoportnál: antiszemita kijelentések és tettek, SzÁLASI éltetése, nyilas karszalag viselése, kényszer nélkül Nyugatra távozás. Különösen ennél a csoportnál ütközik ki az igazolási, valamint a népbírósági eljárások gyakran tapasztalt inkonzekvenciája - ami miatt már a kortársak is gyakran kritizálták az egész eljárásmódot. ${ }^{16}$ Sokszor előfordult ugyanis, hogy nem teljes körűen bizonyított esetekben is súlyos büntetést szabtak ki, míg máskor egészen elnézőnek bizonyultak.

Forrásainkban mindkettőre találunk példát. Egy rendőrtisztviselőt például azért fosztanak meg állásától, mert a Győri Textilműveknél - ahol akkoriban dolgozott — bejelentette, hogy a Hunyadi páncélosokhoz jelentkezik önkéntesként. Az illetővel — aki az igazolási eljárásban azt vallotta, hogy valójában az egyetemi zászlóaljba vonult be, hogy elkerülje a munkaszolgálatot, és ezt bizonyítani is tudta — szemben hozott határozat indoklásában ez áll: ,....a bizottság már egymagában azt a körülményt, hogy a Hunyadi páncélgránátos alakulatba való önkéntes jelentkezését jelentette be fenti cégnél oly súlyos és valótlansága esetén is oly propagandisztikus hatású bejelentés, amely már egymagában is elegendő a legszigorúbb büntetés kiszabására."

Az igazolási eljárások és a népbírósági perek kapcsán tapasztalható bizonytalanságot és következetlenségeket bizonyítja egy rendőrfőfelügyelő esete, akivel szemben első fokon az Igazoló Bizottság állástól való megfosztásról határozott, mert az indoklás szerint tanzászlóaljparancsnokként Budapest 
védelmekor tömegesen küldte halálba beosztottait. A népbírósági vizsgálat azonban ennek épp az ellenkezöjét állapította meg: a másodfokú határozat szerint a fellebbező éppen, hogy igyekezett kivonni magát és alárendeltjeit a harcokból. Az indoklás következőképpen magyarázta az enyhítést (állásvesztés helyett „mindössze” feddésről szólt a népbírósági határozat): „A népbíróság álláspontja szerint igazolás alá vont magatartásával kismértékben sértette a magyar nép érdekeit, mert bár igaz az, hogy úgy a németországi tanfolyamra, mint a Mogyoród körüli harcokra rendelet és parancs alapján kellett mennie, de a népbíróság megítélése szerint mégis nagyobb ellenállást kellett volna igazolás alá vontnak tanúsítania. Így különösen a németországi vezénylésnek testi épsége veszélyeztetése nélkül ellenszegülhetett volna. Éppen ezért - bár semmi adat nincs arra, hogy igazolás alá vont németbarát lett volna , magatartásában felismerhető magyar nép érdekeit sértő jelleg, miért is a népbíróság — figyelembe véve az enyhítő körülményeket, így a szociális és demokratikus magatartását és kiváló szakképzettségét — a rendelkező rész szerint határozott az elsőfokú határozattal szemben."18

Végül egy konkrét igazolási eljárással igyekszünk illusztrálni az eddig körvonalazott jelenséget. Igazolási eljárásunk főszereplöje B. V., egy 1918-ban Dombóváron született segédrendőrfelügyelő, kinek ügyét az I. számú Igazoló Bizottság tárgyalta. Az iratokhoz csatolt 19 kérdéses nyilatkozatból kiderül, hogy B. V. kereskedelmi érettségivel rendelkezett és 1941. júniusa óta szolgált rendőrként. Mielőtt katonai szolgálatot teljesített (a kérdőívböl az is kiderül, hogy tartalékos zászlósként, pilótaként szolgált a szovjet fronton), rövid ideig a dombóvári községházán dolgozott jegyzőgyakornokként, majd — hogy mi okból, az nem derül ki az iratokból — Budapestre költözött, ahol néhány hónapig a Hangya szövetkezetnél volt tisztviselö. Rendőrségi karrierje a kérdőív alapján szépen indult: előbb a IX. kerületi osztályparancsnoksághoz osztották be, majd 1943-tól a II. Karhatalmi zászlóaljnál szolgált oktatótisztként, majd hamarosan az I. Karhatalmi zászlóaljban századparancsnokká nevezték ki. Beosztásánál fogva könnyen felmerülhetett a gyanú az igazolási eljárás során, hogy részt vehetett a „népellenes törvények végrehajtásában" - ahogy a kérdőív fogalmaz. Az igazolás alá vont B. V. e kérdésre a következőképpen felelt: „Beosztásomnál fogva, parancsra néhány alkalommal zsidókíséretben részt vettem. A kísérések alkalmával a zsidók nehéz helyzetén parancs ellenére segítettem, azáltal, hogy a gyermekes anyákat, betegeket, öregeket és csomagjaikat lovaskocsira rakattam, levelek átadását megengedtem." 19

Az igazolás alá vont a fasiszta rendszer ellenes tevékenységre, illetve a népellenes törvények végrehajtásának megakadályozására vonatkozó kérdésre adott válaszában is igyekezett kiemelni zsidómentő tevékenységét. B. V. saját bevallása szerint egy zsidó nő bútorait rejtegette lakásában a zsidótörvény életbelépése után, 1944-ben pedig kétszer is részt vett nyilas tüntetések szétverésében, amiért a „nyilasvezérek megfenyegettek, sőt több ízben le is fényképeztek és fekete listára tettek." ${ }^{\text {20 }}$ A segédfelügyelő ezen felül részletesen leírja, hogyan tagadta meg a német megszállást követő időszakban a nyilasok parancsát, amikor egy zsidókból álló menet kísérésében vett részt. A nyilasok megparancsolták a rendőröknek, hogy lőjék agyon a járni képtelen, öreg és beteg zsidókat, B. V. azonban ezt a parancsot megtagadta és csak rendőrei közbelépésének köszönhette, hogy a rá fegyvert fogó nyilasok végül nem végeztek vele. Ráadásul az igazolandó saját bevallása szerint 10-15 beteg, legyengült zsidót szabadon is engedett, amiért a nyilasok fel is jelentették. A kérdőív tanúsága szerint B. V. egy ízben került bevetésre Budapest ostromakor, de még aznap kivonta magát és egységét a harcokból és többé nem is jelentkezett szolgálattételre.

Végül a kérdőív vagyoni állapotban bekövetkezett változásokra vonatkozó kérdéseiböl - amelyek elsősorban a zsidóktól elkobzott vagyon birtokbavételére voltak kíváncsiak - B. V. családi- és lakásviszonyainak néhány részletéről is információt kapunk: „1944. év januárjában nősülni akartam. Protektiót nem vettem igénybe, ezért félévi szaladgálás ellenére nem kaptam lakást. Mivel a nyár folyamán feltétlenül meg akartam nősülni, és a zsidók összeköltöztetése folyamatban volt, ezért egy egyszobás zsidólakást kiigényeltem." 21

Amint azt korábban már említettük, a zsidó lakás bérlése gyakran súlyosbító tényezőt jelentett az igazolási eljárásban. Nem volt ez másként B. V. esetében sem; a meghallgatások során többször is elökerült ez a kérdés, több tanú is kiemelte ezt a tényezőt, külön hangsúlyozva, hogy az igazolandó annak köszönhette a kiutalt lakást, hogy jó viszonyt ápolt a „zsidó ügyek intézőjével”, egy bizonyos B. föfelügyelővel - aki mellesleg ugyanabban a Tisza Kálmán (ma II. János Pál pápa) téri házban lakott, mint B. V.

Ennél is meglepöbbek — különösen a kérdőívben olvasottak fényében — az igazolási eljárás során $\mathrm{B}$. V. ellen felmerült egyéb vádak, amelyeknek egy rendőr kollégájának feljelentő levele szolgált alapul. ${ }^{22}$ A levél tanúsága szerint B. V. szélsőjobboldali gondolkodású, nyilas karszalagot viselt a há- 
ború utolsó napjaiban, a karhatalom parancsnokaként pedig részt vett egy zsidók által lakott Népszínház utcai lövetésénél és a lakók kirablásánál.

Az 1945. VII. 20-án folytatott első tárgyaláson további részletek kerültek elö. A tanúvallomások alapján azonban igencsak megalapozatlannak tünnek a vádak, az Igazoló Bizottság elött megjelent tanúk beszámolóiból kevés konkrétum derül ki, az egyetlen kézzelfogható „bizonyítéknak” az tekinthető, hogy az igazolás alá vont az ominózus lövöldözést és fosztogatást követően egy géppisztollyal a vállán, ,izzadtan és fáradtan” jelent meg lakóhelyének óvóhelyén.

Mindezek ellenére az Igazoló Bizottság 1945. VII. 27-én úgy határozott, hogy B. V.-t megfosztják állásától. A határozat indoklásában amellett, hogy állítólag jó viszonyban volt egy nyilas rendőrtiszttel, illetve „1944. okt. 16-án a Tisza Kálmán tér 16. számú ház óvóhelyén géppisztollyal jelent meg fáradtan izzadtan olyan benyomást keltve, mint aki az akkor lefolyt terrorcselekményekben résztvett", fö érvként a zsidó lakás igénylése, valamint az ide történő beköltözés szerepelt.

A segédfelügyelö fellebbezést nyújtott be a népbírósághoz, amihez egy 65 aláírást tartalmazó ívet csatolt, amelyben egykori alárendeltjei igazolták, hogy B. V. nem volt szélsőjobboldali érzelmü. A fellebbezést benyújtó kérvényben B. V. a következőképpen igyekezett védeni igazát: „Ez a nyilatkozat, miután azt legénységi állományú alantasaim ilyen számosan írták alá, tartalmát tekintve legeklatánsabb bizonyítéka annak, hogy az ellenem az elsőfokú igazolási határozatban megállapított vádak alaptalanok. Az alantas legénység valóban a legjobban tudja megfigyelni és elbírálni fellebbvalója személyes tulajdonságait. Ha tehát ezek az emberek hosszú időn át tartó együttszolgálás és állandó sủrü érintkezés alapján állítják ki rólam ezt a tiszta demokrácia eszméjének megfelelő erkölcsi bizonyítványt, akkor az abban foglaltak valóságában nem lehet kételkedni."23

A népbíróság 1945. XII. 22-én tárgyalta B. V. fellebbezési ügyét. A fellebbezö által benyújtott, „demokratikus” hozzáállását tanúsító aláírások, valamint újabb tanúk meghallgatása alapján a népbíróság végül úgy döntött, hogy $\mathrm{B}$. V.-t felmenti az ellene felhozott vádak alól, és egyúttal „simán” igazoltnak nyilvánítja.

A segédfelügyelö ügye is jól mutatja, hogy gyakran mennyire egy hajszálon múlott egy-egy rendörségi alkalmazott további sorsa és karrierje. Az igazolási eljárások következetlensége mellett ugyanakkor az is jól látszik, hogy - és ez hatványozottan igaz a rendvédelmi szerveknél dolgozókra mennyire nehéz döntéseket kellett hoznia hétköznapi munkája során minden igazolás alá vontnak a megszállás és a nyilas uralom idején. Mindezt jól illusztrálja az egyik IB-határozat ellen fellebbező nyomozó indoklásában található kijelentés: „Nézetem szerint a tökéletes demokratikus felfogás az igazoló bizottság részéről akkor lett volna, ha belátta volna, hogy ez cselekmény a nyilas korszakban történt, amikor még a rendörök is féltek kötelességüket vagy emberi szívük sugallatát teljesíteni, mert féltek egymás bevádolásától.” Ugyanakkor az is kiderült a rendőrségi Igazoló Bizottságok irataiból, hogy számos rendőr - legyen az egyszerü közrendőr vagy vezető pozícióban lévő tiszt - igyekezett ellenállást tanúsítani az általa jogszerütlennek vagy erkölcstelennek tartott felsőbb utasításokkal szemben.

\footnotetext{
Jegyzetek:

${ }^{1}$ PAPP: 162.p.

281/1945.ME.r.

3 15/1945.ME.r.

${ }^{4}$ Amint az általam vizsgált forrásokból kiderült, az igazolási eljárás során nem minden esetben álltak meg az 1939-es időpontnál. Így például egy rendőr törzsfelügyelő igazolási eljárásában a vádak között szerepelt az is, hogy még 1933-ban egy munkástöntetés során letartóztatott két fiatal munkást.

BFL.XVII.1676.

${ }^{5}$ PAPP: op.cit. 162.p.

${ }^{6}$ A nyilatkozatok forrásértékéről a következőket olvashatjuk ZINNER Tibor tanulmányában: „A kitöltés azonban az igazolás alá vontakra volt bízva, s a 'nyilatkozat'-ok igaz vagy hamis voltát — bármennyire is törekedtek az ellenőrzésre — részben az igazolandókkal szembeni bejelentések alacsony száma és az érdektelenség, másrészt az igazolások körüli huzavonák és az egyre gyakoribb visszásságok miatt nehéz volt megállapítani."

Mindezek ellenére úgy vélem, hogy a nyilatkozatok - éppen azért, mert önbevalláson alapultak — alkalmasak arra, hogy egy-egy igazolás alá vont önmagáról, saját személyiségéről és sorsáról alkotott képét megvilágítsák. ZINNER
} 
${ }^{7}$ Ebben a témakörben az alábbi kérdések szerepeltek a kérdőíven:

- A zsidókra vonatkozó jogszabályok alkalmazásával, illetőleg végrehajtásával kapcsolatban milyen tevékenységet fejtett ki?

- Zsidó üzlet kiárusításában saját maga vagy lemenője, házastársa részt vett-e?

- Vásárolt-e saját maga, vagy házastársa ilyen kiárusításból árut?

- Szerzett-e zsidóktól eredő rádiót, ha igen mikor és milyen körülmények között?

- Beköltözött-e zsidó lakásba, ha igen mikor, miért?

- Hivatalában a felek és a hivatalnoktársai előtti kijelentéseiben a hadviseléssel és az ország lakossága egy részével szembeni bánásmóddal kapcsolatban milyen álláspontot foglalt el?

- A Vörös Hadsereg bevonulásakor szolgálati székhelyén tartózkodott-e, ha nem, hát hol, miért és meddig?

- Mikor jelentkezett szolgálattételre?

BFL XVII.1676. : op.cit.

${ }^{8}$ Ugyancsak Budapesten üléseztek a Pest megyei, valamint a Vidéki Kapitányság alkalmazottainak ügyeit vizsgáló Igazoló Bizottságok is, ezekkel azonban jelen tanulmányunkban nem foglalkoztunk.

BFL.XVII.1676.op.cit.

${ }^{9}$ Loc.cit.

${ }^{10}$ Loc.cit.

${ }^{11}$ Itt nyilvánvalóan túlzásról van szó, hiszen a budapesti rendőrség állománya meg sem közelítette ezt a számot.

Loc.cit.

${ }^{12}$ Loc.cit.

${ }^{13}$ A vizsgálatba csak azon ügyeket vontam be, ahol legalább első fokon ismert a határozat, mintegy egy tucat olyan ügy található a levéltárban, ahol annyira töredékes az anyag, hogy nem ismert az Igazoló Bizottsági határozat, sem a népírósági döntés.

${ }^{14}$ Nagyjából hasonló arányokat találunk a székesfóvárosi alkalmazottaknál: 1945. X. 26. és1946. I. 10. között 42136 jogerős határozatot hoztak az Igazoló Bizottságok, s ezek közül 37351 esetben (88,6\%),„simán” igazolták az alkalmazottakat.

ZINNER : OP.CIT. ; BFL.XVII.1676.op.cit.

${ }^{15}$ Ebben az esetben a fellebbezési eljárás költségeit az államkincstár állta, egyébként miden más ítéletnél a fellebbezőnek kellett kifizetnie azt.

${ }^{16}$ PAPP: op.cit. 171-172.p.

${ }^{17}$ BFL.XVII.1676.op.cit.

${ }^{18}$ Loc.cit.

${ }^{19}$ Loc.cit.

${ }^{20}$ Loc.cit.

${ }^{21}$ Loc.cit

${ }^{22}$ Érdemes a feljelentő levél - amely nem csupán B. V.-re, hanem más rendőrtisztekre vonatkozóan is tartalmaz terhelő adatokat - záró gondolatát idézni, mert jól kifejezi azt a bizalmatlansággal, feszültséggel teli helyzetet, ami körüllengte az igazolási eljárásokat. A feljelentő ezzel zárja levelét: „Kedves elvtárs, amennyire Tőled telik, gondoskodj arról, hogy a demokratikus rendörségen ne szolgáljanak ilyen elemek. [...] Kérlek, az összes karhatalmista tiszteket, akik a múltban azok voltak, szigorúan ellenőrizni. De vigyázz, mert egyiket sem tették vissza a régi helyére. Kicsit furcsa, de ebben van valami tendencia, hidd el nekem."

Loc.cit.

${ }^{23}$ Loc.cit.

Jegyzetekben alkalmazott röviditések:

TANULMÁNYOK

PAPP

ZINNER

PAPP Gyula: Az igazoló eljárások és a háborús bünök megtorlása 1945 után Magyarországon. AETAS, XXIV.évf. (2009) 2.sz. 162-179.p. HU-ISSN 1785-9943.

\section{LEVÉL-, IRAT- ÉS DOKUMENTUMTÁRI GYÜJTEMÉNYEK} zoló eljárások 1945-1949. Történelmi Szemle, XXVIIItévf (1985) 1.sz 118140.p. HU-ISSN 0040-9634.

BFL XVII. 1676.

\section{JOGSZABÁLYOK}

81/1945.ME.r.

15/1945.ME.r.
Budapest Fővárosi Levéltár. A Magyar Királyi Államrendőrséghez kiküldött igazoló bizottságok iratai.

- 81/1945.ME.r. a népbíráskodásról.

— 15/1945.ME.r. az igazoló bizottságokról. 